ks. Józef Zabielski

Uniwersytet Kardynała Stefana Wyszyńskiego w Warszawie

\title{
Personalizm jako imperatyw wartościowania człowieka
}

\section{PERSONALISM AS AN IMPERATIVE OF THE EVALUATION OF MAN}

The proper discovery of the truth about a human being requires referring to personalism as a concept of knowing and evaluating. Normative foundation of personalism comes down to recognizing an individual as a person - who is an ontical foundation of values - and the dignity of every man as 'the image of God' (Gen 1:27). The concept of a human being as a person leads to concrete obligations, such as respecting the independence of a person and the value of his life, the obligation to act 'in the field of liability', respecting the good of individuals and the whole mankind. A personalistic norm is an axiological foundation of proper value judgements and all the actions that protect human health and life. In the article, the author analyses two problems: 1. Personalistic norm as an onthological principle of axiology of man; 2. Personalistic evaluation of man as a challenge for today.

Key words: man, human person, personalism, personalistic norm, man as an 'image of God', axiology, human life, life and value of a human person.

Traktowanie osoby ludzkiej jako celu działania, a nie środka do celu stanowi fundamentalne założenie personalistycznej koncepcji wyjaśnienia natury ludzkiej. Jej normatywna treść sprowadza się do prawdy, że wartość człowieka - jako osoby - jest podstawą powinności etycznej. W godności osobowego bytu ludzkiego zakotwiczony jest wymóg uznania i respektowania każdego człowieka. Każdemu człowiekowi jako osobie należna jest afirmacja ze strony innej osoby. Takie 
rozumienie wartościującej godności człowieka rodzi konkretne powinności: uszanowanie autonomiczności bytu osobowego i wartości życia, zobowiązanie do działania „w polu odpowiedzialności”, respektowanie dobra konkretnych osób oraz całej społeczności ludzkiej. Norma personalistyczna ma szczególne znaczenie w poprawnym wartościowaniu człowieka oraz działaniach związanych z ludzkim zdrowiem i życiem. Rozwijając tytułowy problem, w niniejszych analizach podjęte zostaną dwa zagadnienia: 1 . Norma personalistyczna jako ontologiczna zasada aksjologii człowieka. 2. Personalistyczne wartościowanie człowieka jako wyzwanie współczesności.

\section{Norma personalistyczna jako ontologiczna zasada aksjologii człowieka}

Współczesność charakteryzuje się rewolucyjnym rozwojem w dziedzinie biologii i medycyny, co przekłada się na zmienność norm antropologicznych i pojmowania osoby ludzkiej. Te nowe dokonania i możliwości biotechniczne domagają się stałej konfrontacji z wymogami etyki filozoficzno-teologicznej, ukazującej pełnię wartości i godności osoby ludzkiej. Wymagania te podyktowane są odpowiedzialnością za wartościowanie natury człowieka i ludzkiego życia, do czego potrzebna jest

powszechna mobilizacja sumień i wspólny wysiłek etyczny, aby wprowadzić w czyn wielką strategię obrony życia. Dzisiaj świat stał się areną bitwy o życie. Trwa walka między cywilizacją życia a cywilizacją śmierci. Dlatego tak ważne jest budowanie „kultury życia”: tworzenie dzieł i wzorców kulturowych, które będą podkreślały wielkość i godność ludzkiego życia; zakładanie instytucji naukowych i oświatowych, które będą promowały prawdziwą wizję osoby ludzkiej¹.

Imperatyw ten ukierunkowuje na fundamentalną normę etyczną, jaką jest integralna koncepcja natury osoby ludzkiej oraz niezbywalna wartość ludzkiego życia. Nie można bowiem tworzyć norm ludzkiej egzystencji bez odniesienia do wartości fundamentalnej, która stanowi źródło i uzasadnienie zasad szczegółowych. Fundamentalną zaś zasadą ma być traktowanie człowieka zawsze jako cel działania, nigdy zaś jako środek ${ }^{2}$.

Jan Paweł II, Z czym idziemy w nowe tysiąclecie, Kraków 1997, s. 68-69.

Por.J.Ratzinger, Bioetyka w perspektywie chrześcijańskiej, „Przegląd Powszechny" 3(1992), s. 415-416; J. Wolski, Bioetyka w perspektywie personalizmu, Łódź 2008, s. 3-4. 
Destrukcyjnym zagrożeniem tej zasady jest rozwijający się dzisiaj tzw. pryncypializm ${ }^{3}$. W ramach pryncypializmu oraz zbliżonych kon- Nauka cepcji kazuistycznych ustanawianie norm aksjologiczno-moralnych nie różni się od demokratycznych procedur stanowienia prawa państwowego. Moralność pozostaje na usługach struktur polityczno-państwowych oraz legislacyjno-ekonomicznych, zatracając swoją niezależność i odrębność. Mamy tu do czynienia z prawnym pozytywizmem, który ogarnia także aksjologiczny charakter ludzkiej egzystencji. Celem tak pojmowanej etyki jest utrzymanie pokojowych nastrojów wśród negocjatorów, czemu poświęcane jest życie ludzkie, zwłaszcza u jego początków i przy końcu. Wyrazem tego jest otwieranie drogi dla aborcji i eutanazji, gdzie w procedurach negocjacyjnych o prawie do życia, nie bierze udziału człowiek w okresie prenatalnym lub w okresie dzieciństwa, czy też chory terminalnie lub umierający. Lansuje się tutaj zasadę, że bioetyka winna zajmować się poszczególnymi przypadkami, a nie formułowaniem etycznej teorii.

Zwolennicy takich poglądów uważają, że poszukiwanie teoretycznych podstaw aksjologii jest zbędnym balastem, utrudniającym sprawność w podejmowaniu konkretnych decyzji. Jest to postać tzw. etyki proceduralnej, formująca iluzoryczną niezależność od filozofii i teologii, co skutkuje utratą racjonalnego uzasadnienia w rozróżnianiu dobra i zła na rzecz kultury manipulacji. W takiej koncepcji, z założenia odrzuca się moralną prawdę, pozostając na stanowisku relatywizmu, a wszelkie uprawnienia ludzi ustala się na drodze negocjacji w instytucjach społeczno-państwowych. Przyjmowane zasady pomagają w porządkowaniu dyskusji, nie mają zaś stałej treści i nie są hierarchicznie uporządkowane. W konsekwencji, decydenci mają „wolną rękę" w wyborze kolidujących ze sobą zasad i norm. Stąd też przyjmuje się, że np. zabijanie prima facie jest złe, jednak w celu

Została ona zapoczątkowana w 1979 r. przez T. L. Beauchampa i J. F. Childressa. W latach 80. XX wieku została poddana ostrej krytyce, co doprowadziło do wyłonienia się konkurencyjnych wobec pryncypializmu metod stosowanych w aksjologii osoby ludzkiej, wśród których szczególne miejsce zajmują: bezstronna teoria reguł (Impartial Rule Theory), kazuistyka (Casuistry) oraz etyka cnót (Virtue Ethic). Decydujący jest tu nacisk respektowania autonomii poszczególnych ludzi oraz pluralizmu opinii moralnych. Za najważniejsze uważa się wypracowanie procedur negocjacji, które służą rozwiązywaniu konfliktów w celu utrzymania społecznego pokoju. Zob. T. Biesaga, Personalizm a pryncypializm w bioetyce, s. 1, http://dsz.katowice.pl/e107_plugins/content/dok/bioetyka/r1_personalizm. html, (data dostępu: 12.08.2010 r.). 
ograniczenia bólu, w pewnych okolicznościach, może być jedynym sposobem pomocy człowiekowi cierpiącemu ${ }^{4}$.

Przeciwieństwem takiego instrumentalnego traktowania człowieka jest zasada personalistyczna, która domaga się uporządkowania ludzkich działań według normy opartej na integralnym rozumieniu osoby ludzkiej. Doświadczenie zasadności tej normy ujawnia się już w intuicyjnym doświadczeniu - w bezpośrednich przeżyciach moralnych. Przykładowo, jeśli człowiek zastanawia się, czy powiedzieć prawdę przyjacielowi o jego śmiertelnej chorobie, to podstawą tej decyzji jest przeżycie afirmacji wartości i godności osoby, co jawi się jako normatyw oczywisty i bezdyskusyjny. Kategoryczne wezwanie do poszukiwania właściwego działania zakotwiczone jest w afirmacji chorego jako osoby. Doświadczenie tejże godności ukazuje, że wewnętrzny dylemat nie dotyczy wymagań obyczajowo-kulturowych czy prawno-ekonomicznych, lecz jest dylematem stricte moralnym. Decydująca jest tu norma personalistyczna - wartość i godność bytu osobowego, wszystkie zaś inne wymogi - medyczne, ekonomiczne, techniczne, prawne czy zasady skutecznego dochodzenia do konsensusu - stanowią tylko uboczne względy w tym zakresie. O wartości czynu wyłącznie decyduje dobro osoby, jego zaś słuszność może być doprecyzowana na bazie wiedzy medycznej, psychologicznej, prawnej czy też innych uwarunkowań ludzkich działań ${ }^{5}$.

Fundamentem w rozpoznaniu normy personalistycznej jest problem metaetyczny, sprowadzający się do pokonania przeszkody postawionej przez D. Hume'a, dotyczącej przejścia od tego, „,co jest”, do tego „co być powinno”, czyli od „realnego bytu” do „moralnego porządku”. W koncepcji personalistycznej istnieje takie przejście, a jest ono oparte na etycznym doświadczeniu, stanowiącym postać autentycznego źródła etycznego poznania. Doświadczenie to pozwala ustalić elementarny fakt etyczny, dzięki któremu możliwy jest wgląd w wewnętrzną strukturę moralności, a przede wszystkim rozpoznanie miejsca centralnej konstrukcji tworzącej wzajemne powiązania poszczególnych części i pełnionych przez nie funkcji. W personalistycznym rozumowaniu, moralne doświadczenie oznacza wszelkie bezpośrednio poznawcze ujęcie rzeczywistości, które w relacji do moralności polega na przeżyciu bezwzględnej powinności spełnienia (lub nie spełnienia) określonych czynów jako dobre lub złe. Analiza tego przeżycia pozwala sprecyzować jego treściową zawartość, co wyraża się w stwierdzeniu, że jest

Por. tamże, s. 1-2. Zob. A. Vicini, Auf der Suche nach einer universalen Ethik, „Concilium” [niem.], 46(2010), nr 3, s. 339-346.

Por. T. Biesaga, Personalizm a pryncypializm $w$ bioetyce, dz. cyt., s. 3 . 
to afirmacja osoby ludzkiej ze względu na nią samą - ze względu na przysługującą jej wartość i godność.

Tak rozpoznaną normę personalistyczną wyrażają konkretne sformułowania, niektóre zakotwiczone w filozofii starożytnej: Homo homini res sacra (Człowiek człowiekowi jest świętością), Homo homini summum bonum (Człowiek człowiekowi jest najwyższym dobrem), przede wszystkim zaś stwierdzenie z czasów scholastyki: Persona humana est affirmanda propter se ipsum (Osobę ludzką należy afirmować ze względu na nią samą). Ma to też odniesienie do imperatywu I. Kanta, który stwierdza, że każda osoba ludzka jest dla siebie celem, nigdy zaś środkiem do celu. W każdym z tych ujęć osoba ludzka stanowi przedmiot bezpośredniego ujęcia w aspekcie należnej jej godności, która domaga się bezwzględnej afirmacji - uznania i szacunku. Oznacza to, że osobowa godność każdego człowieka jest aktem intuicyjnego ujęcia jej intelektualnego doświadczenia ${ }^{6}$.

Treść normy została doprecyzowana w personalistycznej koncepcji etyki, którą w Polsce prezentuje zwłaszcza K. Wojtyła. On to zasadę i normę personalistyczną ujmuje następująco:

Norma ta jako zasada o treści negatywnej stwierdza, że osoba jest takim dobrem, z którym nie godzi się używanie, które nie może być traktowane jako przedmiot użycia i w tej formie jako środek do celu. W parze z tym idzie treść pozytywna normy personalistycznej: osoba jest takim dobrem, że właściwe i pełnowartościowe odniesienie do niej stanowi tylko miłość. I tę właśnie pozytywną treść normy personalistycznej eksponuje przykazanie miłości ${ }^{7}$.

Poprawne zrozumienie tak sformułowanej normy oraz jej zastosowanie w konkretnym działaniu, domaga się doprecyzowania pojmowania osoby ludzkiej i jej dobra. Poszukiwania te kierują ku antropologii, w celu wyjaśnienia rozumienia natury osoby oraz jej obiektywnego dobra. Nie wystarcza tu bowiem utylitarne pojęcie doraźnych korzyści, co daje technice pierwszeństwo przed etyką. Personalistyczne zaś poszukiwanie obiektywnego dobra osoby chroni ludzkie działanie przed dehumanizacją, przed tendencjami techno-totalitarnymi,

$6 \quad$ Por. T. Ślipko, Spacerem po etyce, Kraków 2010, s. 205-27; T. Styczeń, Etyka niezależna?, Lublin 1980, s. 14-15; T. Biesaga, Personalizm a pryncypializm $w$ bioetyce, dz. cyt., s. 3; J. B. Martínez Porcell, L'ontologia della persona come subsistens distinctum secondo san Tommaso d'Aquino, „Angelicum” 87(2010), vol. 2, s. 383-403.

$7 \quad$ K. Wojtyła, Miłość $i$ odpowiedzialność, Lublin 1982, s. 42. Por. R. Guerra Lopez, Repensarla vida moral. Experiencia moral, teoría de la moralidad y antropología normativa en la filosofia de Karol Wojtyla, „Tópicos. Revista de filosofía”, 2006, nr 31, s. 83-102. 
w ramach których człowiek staje się niewolnikiem własnych wytworów technicznych .

Odkrywanie prawdy o podmiotowości osoby ludzkiej i jej godności dokonuje się w doświadczeniu człowieka. W polu tego doświadczenia człowiek jawi się jako szczególne suppositum (podmiot), a równocześnie jako konkretne - jedyne i niepowtarzalne ,,ja”. Doświadczenie to pozwala człowiekowi rozpoznać siebie jako podmiot i przedmiot, jako tego „kto” doświadcza oraz tego „kogo” doświadcza. Człowiek jest sobie samemu dany jako ten, który istnieje (bytuje) i działa. To doświadczenie jest udziałem wszystkich ludzi. W doświadczeniu własnego ,ja” dokonuje się zrozumienie podmiotowości człowieka, obrazu osoby jako podmiotu. Chodzi tu jednak o całościowe doświadczenie człowieka, a nie tylko o jakieś elementy - funkcje lub części struktury - bytu osobowego. Rozpoznając w doświadczeniu człowieka jako suppositum, równocześnie doświadczamy możliwości i powinności prawidłowego myślenia o nim jako o podmiocie własnego istnienia i działania. Te treści zawierają się w pojęciu suppositum, które służy do stwierdzenia podmiotowości człowieka w znaczeniu metafizyczno-antropologicznym. W tym znaczeniu człowiek jest pojmowany „trans-fenomenalnie” czyli „poprzez-zjawiskowo”. Doświadczenie wszystkich fenomenów składających się na całokształt ludzkiego istnienia (esse), pozwala człowiekowi dostrzec w nim samym podmiot jako jedynie możliwy sposób istnienia i działania. Metafizyczna podmiotowość - suppositum - jako podstawowy wyraz doświadczenia człowieka jest równocześnie gwarantem tożsamości tegoż człowieka w jego bytowaniu i działaniu. Stwierdzenie bowiem suppositum człowieka równocześnie wyraża jego nienaruszalność, a równocześnie otwartość na wszystko, co wnosi doświadczenie własnego ,ja” w rozumienie podmiotowości osoby. Poznając zaś człowieka w jego wymiarze metafizyczno-antropologicznym sięga się korzeni jego bytowania, co jednak nie przesłania poszczególnych aspektów tegoż bytu, umożliwiając zrozumienie go $\mathrm{w}$ całym bogactwie jego istnienia (esse $)^{9}$.

Poznając w wewnętrznym doświadczeniu swoją naturę i jej działanie, człowiek przeżywa swoją tożsamość i jedność, czyli bytową niepodzielność. Doświadczenie zaś tej jedności wskazuje na tożsame źródło ludzkiej aktywności, zakotwiczone w ludzkim ,,ja”. Tym źródłem oraz

$8 \quad$ Por. T. Biesaga, Personalizm a pryncypializm w bioetyce, dz. cyt., s. 3; Zob. także: R. G. López, Afirmar a la persona por sí misma. La dignidad como fundamento de los derechos de la persona, México 2003.

$9 \quad$ Por. K. Wojtyła, Osoba: podmiot i wspólnota, „Personalizm” 5(2003), s. 15-52. Zob. także: P.S. Mazur, Doświadczenie wewnętrzne jako podstawa formowania koncepcji osoby, „Zeszyty Naukowe KUL”, 52(2010), nr 1(209), s. 59-68. 
ontyczną podstawą godności człowieka jest obecność pierwiastka duchowego ( $\varphi v x \eta ́-p s y c h e ́)$, który stanowi centrum tożsamości i niepo- Nauka dzielności ludzkiego bytu oraz transcendencji wobec świata nieosobowego. Doświadczanie jedności i tożsamości działającego „ja” oznacza, że człowiek posiada zdolność decydowania o sobie i o swoim działaniu. Ten świadomie i dobrowolnie działający podmiot jest osobą, czyli owym „ja” rozumnej natury. Koncepcja osoby nie jest bowiem dedukowana z jakiegoś teoretycznego systemu filozoficznego, ale „osoba” jest nam dana w wewnętrznym doświadczeniu bycia człowiekiem. Byt osobowy stanowi punkt wyjścia w rozumieniu człowieka, a nie punkt dojścia egzystencjalnego faktu istnienia osoby. Takie rozpoznanie człowieka stawia go w pozycji wyjątkowej jako tego, który jest przedmiotem poznania i doświadczenia oraz oddziaływania, zarówno wewnętrznego, jak i zewnętrznego ${ }^{10}$.

Zakotwiczona w naturze osobowego bytu człowieka norma personalistyczna poprzedza zasadę autonomii, dobroczynności, sprawiedliwości czy unikania zła. Jest to norma normans (zasada normująca) dla wszystkich pozostałych zasad, gdyż ukazuje, że to osoba jest podstawą ludzkich zachowań moralnych, a nie jakaś bezosobowa rzeczywistość, jak np. nakazy prawa czy normy społeczno-obyczajowe. Tylko bowiem po określeniu obiektywnego dobra osoby, można stwierdzić zasadność dobroczynności lub braku szkody. Bez ustalenia obiektywnego dobra osoby, za dobroczynność można uznać różne działania antyhumanistyczne i szkodliwe dla człowieka, np. że w interesie pacjenta jest jego aborcja czy eutanazja.

Należy wziąć pod uwagę, że zasada afirmacji osoby dla niej samej ma szersze znaczenie niż zasada autonomii. Norma personalistyczna bowiem swoim zakresem treściowo-normatywnym obejmuje każdą osobę, każdego człowieka, bez względu na stan jego rozwoju, chorobę czy użyteczność społeczną. Nie można z niej wykluczyć człowieka $\mathrm{w}$ okresie prenatalnym, terminalnie chorego, nieprzytomnego czy umierającego. Norma ta przeciwstawia się tzw. selektywnemu humanizmowi, w ramach którego pewnym ludziom przypisuje się prawa osobowe, innym zaś są one odbierane. Norma personalistyczna bowiem nie wywodzi się z biologicznej wartości życia, lecz odwrotnie: to osoba swoim istnieniem sprawia, że jej życie biologiczne, psychiczne, itp. jest wartościowe. W tym wymiarze wartość istnienia osoby, wartość ludzkiego życia, nie może być przedmiotem uzgodnień czy społecznego konsensusu, nie może też być nadawana czy odbierana przez

$10 \quad$ Por. J. Zabielski, Odpowiedzialność za życie, Białystok 2007, s. 17-23; B. V. Johnstone, From physicalism to personalism, „Studia Moralia” 30(1992), nr 1, s. 83-85. 
decyzje ekspertów, etyczne komisje czy państwo. Życie osoby ludzkiej jest wartością autoteliczną (samą w sobie) i nie podlega żadnemu porównywaniu czy przeliczaniu. Ludzkie życie jest wartością jedyną i niepowtarzalną, tak jak jedyna w swoim rodzaju i niepowtarzalna jest każda osoba ludzka ${ }^{11}$.

\section{Personalistyczne wartościowanie człowieka jako wyzwanie współczesności}

Analizując różne stany ludzkiej egzystencji najpierw trzeba stwierdzić, że norma personalistyczna jest zasadą działania odnoszącą się do wszelkich sytuacji w ludzkim życiu. Norma ta bowiem ujmuje osobę w jej ontycznej naturze i istnieniu. Należy pamiętać, że zjawisko świadomości człowieka (homo cogitans), jego akty wolnościowe (homo liber), posługiwanie się językiem (homo loquens), zdolności twórcze (homo faber), itp., są objawami istnienia osoby i jej natury. Fakt, że te przejawy ludzkiej aktywności jawią się jako pierwsze w naszej obserwacji (ordo cognoscendi) nie oznacza, że człowiek w okresie życia prenatalnego, w dzieciństwie, podczas snu czy ciężkiej choroby biologicznej lub psychicznej, nie jest człowiekiem lub jest „mniej człowiekiem” (ordo essendi). Wszystkie te przejawy ludzkiej egzystencji są bowiem wtórne wobec natury osoby, którą ona posiada od swego początku. Zatrzymywanie na nich lub dawanie im pierwszeństwa jest myśleniem wyłącznie fenomenalistycznym lub funkcjonalistyczno-aktualistycznym, nie ujmującym istoty natury osoby ludzkiej.

Współcześnie - niestety - coraz częściej obserwuje się wprost zanik myślenia metafizycznego, co objawia się zacieraniem ontycznej różnicy między człowiekiem a zwierzęciem. Prezentowany w ten sposób witalistyczny monizm przekreśla naturę zwierząt i ludzi, co prowadzi do fatalnych skutków w etyce. Niektórzy - np. P. Singer,

11 Por. T.Biesaga, Personalizma pryncypializmwbioetyce, dz.cyt., s. 3-4; Cz.S. Bartnik, Ontologia personalizmu, „Personalizm” 5(2003), s. 77-84; J. Zabielski, Odpowiedzialność za życie, dz. cyt., s. 159-188; A. Lendzion, Koncepcja podmiotu osobowego w personalizmie Jacques'a Maritaina, ,Roczniki Pedagogiczne”2010, t. 2(38), s. 5-20. Personalista J. Maritain integralność osoby ludzkiej i jej normatywność charakteryzuje następująco: „Osoba to wszechświat o naturze duchowej, obdarzony wolnością wyboru i stanowiący tym samym całość niezależną od świata. Ani natura, ani państwo nie mają dostępu do tego wszechświata bez pozwolenia. I nawet Bóg, który jest i działa wewnątrz, działa w nim w sposób szczególny i z przedziwną delikatnością, która wskazuje, jak bardzo się z nim liczy: szanuje jego wolność, choć mieszka w jej sercu, pobudza ją, lecz nigdy nie zadaje jej gwałtu”. J. Maritain, Humanizm integralny: zagadnienia doczesne i duchowe nowego świata chrześcijańskiego, Londyn 1961, s. 16. 
Z. Bauman - twierdzą, że nowo narodzone dziecko nie jest rozumnym i samoświadomym istnieniem, zaś istnieje wiele innych istot, których Nauka „rozumowanie” i spostrzegawczość oraz zdolność odczuwania są bardziej rozwinięte. Stąd też - twierdzą - życie nowo narodzonego dziecka ma mniejszą wartość niż życie np. psa czy szympansa. W konsekwencji podkreślają, że do eksperymentów medycznych należy używać ludzi z uszkodzonym mózgiem, nie zaś zwierzęta. Embrion ludzki traktują nie jako istotę osobową, ale jako rzecz, noworodki z bezmózgowiem lub zespołem Downa należy uznać za umarłe i użyć do transplantacji. O prawie do życia rozstrzyga bowiem moment „stania się” osobą, który nie jest określony ani czasowo, ani formalnie. Idąc tokiem takiego „rozumowania” można powiedzieć, że ten, kto głosi wykluczenie innych ludzi z prawa do życia sam nie jest osobą, gdyż nie posiada cech moralnych wyróżniających istnienie osobowe, a raczej okazuje cechy ujawniające się w świecie zwierząt ${ }^{12}$.

Ontyczne podstawy osoby ludzkiej oraz zakotwiczona w nich norma personalistyczna winny stanowić normatyw kwalifikacji wszelkich zagrożeń ludzkiej egzystencji oraz sposobów traktowania człowieka. Najogólniej biorąc, życie ludzkie jest dzisiaj najbardziej zagrożone od poczęcia do narodzin oraz dobiegające końca. Uwzględniając charakter oraz ilość owych zagrożeń, często określa się je dzisiaj mianem „zamachów" na ludzkie życie. Wymiar etyczny tego zagadnienia wyraża się w tym, że

w świadomości zbiorowej te zamachy na życie tracą stopniowo charakter „przestępstwa” i w paradoksalny sposób zyskują status „,prawa”, do tego stopnia, że żąda się uznania ich pełnej legalności przez państwo, a następnie wykonywania ich bezpłatnie przez pracowników służby zdrowia. Zamachy te uderzają w ludzkie życie, gdy jest ono najsłabsze i całkiem pozbawione możliwości obrony. Jeszcze groźniejszy jest fakt, że w dużej mierze dochodzi do nich w gronie rodziny i za sprawą rodziny, która przecież ze swej natury powinna być „sanktuarium życia”"13.

Uwarunkowania owych „zamachów” na ludzkie życie koncentrują się wokół kryzysu kultury moralnej i zatracaniu sensu życia, co z kolei

12 Por. T.Biesaga, Personalizm a pryncypializm wbioetyce, dz.cyt., s. 4-5; P. Singer, Practical Ethics, Cobridge 1979, wyd. pol. Etyka praktyczna, tłum. A. Sagan, Warszawa 2003, s. 149-150, 169-173, 192; zob. także: P. Singer, Animal Liberation, New York 1975; Z. Bauman, Etyka ponowoczesna, tłum. J. Bauman, J. TokarskaBakir, Warszawa 1996, s.51-110; M. Munzarova, Dignity, Personhood and Culture: Reflections on Bioethics of today, „Medicina e morale. Rivista internazionale die Bioetica", 2010, nr 4, s. 547-556.

13 Jan Paweł II, Encyklika Evangelium vitae, nr 11. Por. J. Zabielski, Odpowiedzialność za życie, dz. cyt., s. 64 . 
wiąże się z deformacją pojmowania i traktowania człowieka jako osoby ludzkiej. Sytuacja ta sprawia, że

wartość życia ulega dziś swoistemu „przyćmieniu”, chociaż sumienie nieustannie przypomina o jego świętości i nienaruszalności, czego dowodem jest fakt, że próbuje się przesłaniać niektóre przestępstwa przeciw życiu poczętemu lub zmierzającemu ku naturalnemu końcowi określeniami typu medycznego, które mają odwracać uwagę od tego, że w rzeczywistości zagrożone jest prawo konkretnego człowieka do istnienia ${ }^{14}$.

Na takie wartościowanie życia i jego traktowanie wielki wpływ mają współczesne tendencje kulturowo-społeczne oraz polityczno-gospodarcze, gdzie za najwyższe kryterium działania uważa się osobisty sukces i materialny zysk. W konsekwencji, w relacjach międzyludzkich mają miejsce wojny silnych przeciw słabym lub bezsilnym. Wielu współczesnych ludzi uważa, że życie wymagające większej troski i życzliwej opieki, jest bezużyteczne lub jest traktowane jako nieznośny ciężar, co kończy się jego odrzuceniem i zniszczeniem.

Człowiek, który swoją chorobą, niepełnosprawnością lub - po prostu - samą swoją obecnością zagraża dobrobytowi lub życiowym przyzwyczajeniom osób uprzywilejowanych, bywa postrzegany jako wróg, przed którym należy się bronić albo którego należy wyeliminować. Powstaje w ten sposób swoisty „spisek przeciw życiu”. Wciąga on nie tylko pojedyncze osoby w ich relacjach indywidualnych, rodzinnych i społecznych, ale sięga daleko szerzej i zyskuje wymiar globalny, naruszając i niszcząc relacje łączące narody i państwa ${ }^{15}$.

Taka sytuacja światopoglądowo-aksjologiczna ukazuje brak personalistycznego traktowania człowieka oraz wynaturzenie ludzkiej egzystencji. Wyjątkowo rażącym tego dowodem jest dopuszczanie zabijania dzieci nienarodzonych. Zwolennicy takich poglądów nie liczą się z danymi nauki, które pozwalają dziś jednoznacznie stwierdzić, że pojęcie osoba ludzka

zakłada jedność tejże z indywidualną istotą rozwijającą się w embrionie i obecną od chwili zapłodnienia. Od momentu zapłodnienia embrion przynależy do porządku „być”, nie zaś do porządku „mieć”. Jest on odrębnym bytem ludzkim, który żyje lub żył, czego żadne prawo zmienić

$14 \quad$ Jan Paweł II, Encyklika Evangelium vitae, 11.

15 Tamże, nr 12. Por. R. Otowicz, Ideologiczne zagrożenia daru życia $w$ centrum uwagi wspótczesnej kwestii społecznej, [w:] Życie - dar nienaruszalny. Wokót encykliki,„Evangelium vitae”, A. Młotek, T.Reroń(red.), Wrocław 1995, s. 193-204; V. Bilasová, Filozofické problémy medicínskejetiky, „Parerga. Międzynarodowe Studia Filozoficzne", 2008, nr 2, s. 141-150. 
nie może. Jest on osobą, a nie rzeczą, ,ani materiałem, ani tworem”. [...] Nie ma kolejnych progów stawania się człowiekiem. Natura ludzka jest obecna wraz ze swymi potencjalnościami, i oznacza to coś zupełnie innego niż być tylko potencjalnie człowiekiem; przecież nie można być bardziej lub mnie rzeczą, bardziej lub mniej osobą. Szacunek dla niej nie ma więc charakteru dowolności ${ }^{16}$.

Filozoficzno-personalistyczne uzasadnienie początku ludzkiego życia oparte jest na danych współczesnych nauk biologicznych, a zwłaszcza genetyki. Odwołując się do tych danych, światowej sławy francuski genetyk prof. J. Lejeune stwierdza:

Obiektywnie istnieje tylko jedna możliwa definicja ludzkiej istoty: istota ludzka jest członkiem naszego gatunku. Jej ludzka natura zostaje określona przez genetyczne dziedzictwo ludzkiego gatunku, jakie otrzymuje od swoich rodziców. Embrion jest więc częścią ludzkiego gatunku. Zapłodnienie wyznacza początek życia, tzn. pojawienie się nowej istoty ludzkiej, jedynej i niepowtarzalnej. [...] W rzeczywistości bowiem, nie ma żadnej różnicy w naturze między embrionem, płodem a dzieckiem po urodzeniu: we wszystkich przypadkach chodzi o tę samą osobę w różnych stadiach rozwoju ${ }^{17}$.

Argumentacja tego typu w pełni i przekonująco uzasadnia personalistyczną normę w traktowaniu życia ludzkiego i jego obronę od chwili poczęcia. Tylko ta bowiem norma, jako zasada działań wobec dziecka nienarodzonego, w sposób trwały chroni dobro osoby ludzkiej oraz jej wartość i godność.

Naruszeniem normy personalistycznej, a tym samym zamachem na ludzkie życie jest też sztuczna prokreacja człowieka. Mamy tu do czynienia $z$ destrukcją osoby ludzkiej w postaci braku uznania i uszanowania osobowej natury człowieka w jego prawie do życia i integralności cielesnej od poczęcia do naturalnej śmierci. Wyraża się to zwłaszcza $\mathrm{w}$ niszczeniu życia w stanie embrionalnym oraz w czysto instrumentalnym traktowaniu embrionów. Specjaliści od metod zapłodnienia in vitro uważają, że tego rodzaju „straty” należy zaakceptować jako cenę pozytywnych rezultatów tego rodzaju poczęcia. W konsekwencji metody zapłodnienia in vitro są akceptowane, embrion zaś staje się

$16 \quad$ J.-M. Varaut, Możliwe, leczzakazane. O powinnościach prawa,tłum. S. Szwabski, Warszawa 1996, s. 51. Por. J. Zabielski, Wolność a prawa człowieka w postmodernistycznej kulturze końca XX wieku, „Studia Teologiczne” 14(1996), s. 7586; J. L. Brugues, L'éthique dans un monde désenchanté, „Revue Thomiste” 102(1994), t. 44, nr 2, s. 195-210.

17 Cyt. za: K. Gawron, Pierwszy żotnierz Jana Pawta II, „Niedziela” 15(1995), s. 6. 
„rywalem” wobec ludzkich pragnień i życie człowieka w stanie embrionalnym poświęca się dla ich zaspokojenia ${ }^{18}$.

Naruszeniem osobowej godności i zagrożeniem życia człowieka jest też zamrażanie embrionów i ich utylitarne traktowanie. Wyrazem braku szacunku dla wartości i godności życia osobowego jest także wykorzystanie ludzkich embrionów w celach badawczych oraz przeznaczenie ich do celów terapeutycznych, gdzie są traktowane jako tzw. materiał biologiczny, skazany na zniszczenie. Takie traktowanie ludzkiego życia stanowi charakterystyczny paradoks współczesności i w sposób niezwykle drastyczny ukazuje przedmiotowe traktowanie osoby ludzkiej w ramach sztucznej prokreacji. Należy więc podkreślić, że „redukcja embrionów jest zamierzoną aborcją selektywną. Jest to bowiem rozmyślne i bezpośrednie zniszczenie jednej lub wielu niewinnych istot ludzkich w początkowej fazie ich istnienia i jako takie stanowi zawsze nieporządek moralny"

Zaniechanie personalistycznego wartościowania ludzkiego życia obserwuje się też w traktowaniu ludzi chorych i umierających. Coraz częściej dochodzi do głosu trend społeczno-kulturowy, w ramach którego „bardzo trudno jest przyjąć i znosić cierpienie, a zatem zwiększa się pokusa rozwiązywania problemu cierpienia, eliminując go u podstaw przez przedwczesne spowodowanie śmierci w momencie uznanym za właściwy"20. Jest to wyraz prometeizmu współczesnego człowieka, który łudzi się, że w ten sposób zapanuje nad życiem i śmiercią; w rzeczywistości zostaje pokonany przez śmierć, w której nie rozpoznaje żadnego sensu i nadziei.

Poznanie współczesnych koncepcji pojmowania człowieka oraz postaw wobec wartości i godności ludzkiego życia nie napawają satysfakcją i radością i uświadamiają, że deformacja osoby ludzkiej przybiera coraz większe rozmiary. Najgorsze jest to, jak podkreśla Jan Paweł II, że „, «są to zagrożenia zaprogramowane w sposób naukowy

18 Por. Kongregacja Nauki Wiary Instrukcja Dignitas personae, nr 14-15; J.Zabielski. Sztuczna prokreacja jako destrukcja osobowej godności człowieka, [w:] Świętość ludzkiego życia, T. Reroń (red.), Wrocław 2009, s. 234-236.

19 Kongregacja Nauki Wiary, Instrukcja Donum vitae, nr 21. Por. R. Spaemann, Menschenwürde undmenschliche Natur „Communio”[niem.], 39(2010), s. 134-139; J. Zabielski, Fertilisierung in-Vitro. Die Sicht der Kirche, [w:] Ethisch relevante Techniken der Biologen, A. Laun, A. Marcol (red.), Opole 2003, s. 25-31.

20 Jan Paweł II, Encyklika Evangelium vitae, 15. Zob. J. Zabielski, Odpowiedzialność za życie, dz. cyt., s. 69. 
i systematyczny. Wiek XX zapisze się jako epoka masowych ataków na życie, jako nie kończąca się seria wojen i nieustanna masakra niewin- Nauka nych istot ludzkich. Fałszywi prorocy i fałszywi nauczyciele odnieśli w tym stuleciu największe sukcesy»"21. Zmiana takiej postawy wobec ludzkiego życia wymaga przywrócenia człowiekowi właściwej mu godności, uznając w każdym człowieku - od poczęcia do naturalnej śmierci - byt osobowy, posiadający nienaruszalną wartość. Takie zaś rozpoznanie i traktowanie człowieka zapewnia przyjęcie i stosowanie personalistycznej normy w wartościowaniu każdego człowieka oraz troskę o jego życie.

Słowa kluczowe: człowiek, osoba ludzka, personalizm, norma personalistyczna, człowiek jako „obraz Boga”, aksjologia, życie człowieka, wartość i godność osoby ludzkiej.

21 Jan Paweł II, Encyklika Evangelium vitae, 17. Por. C. A. Anderson, Ludzka godność, prawo do życia i konstytucja, „Znaki Czasu” 2(1991), s. 55-69. 